\title{
MORPHO-BIOLOGICAL PARAMETERS OF CORN CROPS AND PHOTOSYNTHETIC PRODUCTIVITY
}

Piliarska O. O.

\section{INTRODUCTION}

In southern part of the steppe zone of Ukraine, the main factors limiting the intensity of productive processes and the level of grain yield of corn seeds are: water regime, content and availability of nutrients, the amount of fertilizer application, the lack of which hinders obtaining of high and stable yields ${ }^{1,2}$.

Therefore, development of new and improvement of existing elements of the scientifically based cultivation technology of new hybrids of corn, studying of action and interaction of irrigation regimes, doses of mineral fertilizers and plant density, which most significantly influence on their productivity in the conditions of southern Ukraine, is relevant. By the scale of distribution, versatility of use and energy nutritive value corn is the most important grain and fodder crop $^{3}$.

The aim of our study was to improve the elements of cultivation technology of corn hybrids in the conditions of irrigation in the South of Ukraine.

The processes of productivity formation of corn hybrids depending on the conditions of humidification, doses of mineral fertilizers and density of plants were investigated in the conditions of the South of Ukraine on darkchestnut middle-loamy soil. Growing patterns, patterns of the development and dynamics of plant productivity formation were determined, the indicators of water consumption of corn plants and efficiency of water use by the stages of their growth and development were defined. The elements of the technology of corn seeds growing in the conditions of irrigation in the South of Ukraine, which ensure lower costs of irrigation water and other resources to obtain the seed unit, the reaction of corn plants on changing background of mineral nutrition and a plants density were improved.

\footnotetext{
1 Лавриненко Ю.О., Вожегова Р.А., Коковіхін С.В. та ін. Кукурудза на зрошуваних землях півдня України: монографія. Херсон: Айлант, 2011. 468 с.

${ }^{2}$ Нікішенко В.Л., Писаренко В.А. та ін. Методичні вказівки з планування та управління еколого-безпечними, водозберігаючими й економічно обгрунтованими режимами зрошення сільськогосподарських культур. Херсон: Олді-плюс, 2010. 152 с.

${ }^{3}$ Вожегова Р.А., Лавриненко Ю.О., Малярчук М.П., Власенко О.О. та ін. Наукові підходи до формування технології вирощування зернових та технічних культур в умовах 2011 року: науково-методичні рекомендації. Херсон: Айлант, 2011. 36 с.
} 
Experiments were conducted with the hybrid of the middle-ripening group (FAO 240), Kros 221M, which is as a maternal form for many modern corn hybrids (Syvash, Ingulsky, Genichesky, etc.).

An important condition for the formation of high crop yields is a sufficient increase in vegetative mass. The absolute value of its increase is the external manifestation of internal processes, which take place in plants. Therefore, the rate of increase in the surface mass could be used to contemplate about the impact of any factor on the plant ${ }^{4,5}$.

Scientists note the close link between the crop yield and the mass of its vegetative bodies. After all, plants mobilize from vegetative biomass carbohydrates, nitrogen and other substances for the formation of the reproductive part of their yield ${ }^{6}$.

Field experiments, laboratory and analytical studies for 2009-2018 years were carried out at the Institute of Irrigated Agriculture of the National Academy of Agrarian Sciences of Ukraine, located on the right bank of the Dnipro River in the zone of the Ingulets irrigation system. According to the schemes the study provided for investigation of such factors as density of plants, various nutritional and watering regimes.

\section{Dynamics of crude plant biomass accumulation}

According to the scientific sources, the biggest crude biomass per one plant of corn in the conditions of irrigation is reached at the wax ripeness stage of grain ${ }^{7,8}$.

It should be noted that in the initial stages of plant growth and development (sprouts - 7 leaves) the intensity of accumulation of surface biomass was not high, the indicator of which fluctuled within 106-112 g per 1 plant (Table 1 ).

The greater increase in crude biomass per plant of corn in our observations was fixed on all the variants of the experiment starting from an inter-stage period of 11 leaves - flowering. So, if at the stage of 7 leaves the

\footnotetext{
4 Алиев Д.А. Фотосинтетическая деятельность растений в посевах, минеральное питание и продуктивность растений. Баку: ЭЛМ, 1974. 335 с.

5 Косарський В.Ю., Грицун О.Л., Патюшенко С.О. Вплив густоти рослин на врожайність зерна кукурудзи. Агроном. 2010. № 3. С. 70-72.

${ }^{6}$ Вожегова Р.А., Лавриненко Ю.О., Коковіхін С.В., Грабовський П.В. та ін. Екологомеліоративне та економічне обгрунтування ефективності систем управління продукційними і технологічними процесами основних культур на зрошуваних землях південного регіону. Херсон: ВЦ ІЗПР НААН України, 2010. 26 с.

${ }^{7}$ Гуляев Б.И. Количественные основы взаимосвязи фотосинтеза, роста и продуктивности растений: автор. дис. работы доктора биол. наук, ИФР АН УССР / Б.И. Гуляев. К., 1983. 49 c.

8 Лавриненко Ю.О., Рубан В.Б., Михаленко І.В. Наукове обгрунтування технології вирощування кукурудзи при краплинному зрошенні: монографія. Херсон: Айлант, 2014. $194 \mathrm{c}$.
} 
difference between the variants was low and averaged to about 1-6 g per plant, then at the stage of 11 leaves, comparing the variants with and without irrigation, the difference was 35-38 g.

Table 1

Dynamics of accumulation of crude biomass by corn plants, g per 1 plant

\begin{tabular}{|c|c|c|c|c|}
\hline \multirow{2}{*}{$\begin{array}{c}\text { Conditions of } \\
\text { humidification }\end{array}$} & \multirow{2}{*}{$\begin{array}{l}\text { Mineral nutrition } \\
\text { background }\end{array}$} & \multicolumn{3}{|c|}{$\begin{array}{l}\text { Density of plants, thousand } \\
\text { pcs/ha }\end{array}$} \\
\hline & & 40 & 60 & 80 \\
\hline \multicolumn{5}{|c|}{ Inter-stage period $6-7$ leaves } \\
\hline \multirow{3}{*}{ Without irrigation } & Without fertilizers & 107 & 106 & 106 \\
\hline & Calculated dose & 110 & 107 & 108 \\
\hline & Recommended $\mathrm{N}_{120} \mathrm{P}_{90}$ & 112 & 109 & 109 \\
\hline \multicolumn{5}{|c|}{ Inter-stage period 9-11 leaves } \\
\hline \multirow{3}{*}{ Without irrigation } & Without fertilizers & 272 & 265 & 264 \\
\hline & Calculated dose & 278 & 268 & 270 \\
\hline & Recommended $\mathrm{N}_{120} \mathrm{P}_{90}$ & 282 & 270 & 273 \\
\hline \multirow{3}{*}{$\begin{array}{c}\text { Biologically } \\
\text { optimal 70-80-70\% } \\
\text { FC in the soil layer } \\
0-50 \mathrm{~cm}\end{array}$} & Without fertilizers & 314 & 309 & 296 \\
\hline & Calculated dose & 317 & 310 & 302 \\
\hline & Recommended $\mathrm{N}_{120} \mathrm{P}_{90}$ & 324 & 312 & 304 \\
\hline \multirow{3}{*}{$\begin{array}{l}\text { Water-saving } 70- \\
70-70 \% \text { FC in the } \\
\text { soil layer } 0-50 \mathrm{~cm}\end{array}$} & Without fertilizers & 311 & 306 & 294 \\
\hline & Calculated dose & 314 & 308 & 299 \\
\hline & Recommended $\mathrm{N}_{120} \mathrm{P}_{90}$ & 321 & 309 & 301 \\
\hline \multirow{3}{*}{$\begin{array}{c}\text { Soil-protective } \\
70-70-70 \% \text { FC in } \\
\text { the soil layer } 0-30 \\
\text { cm }\end{array}$} & Without fertilizers & 310 & 305 & 293 \\
\hline & Calculated dose & 313 & 307 & 298 \\
\hline & Recommended $\mathrm{N}_{120} \mathrm{P}_{90}$ & 320 & 308 & 300 \\
\hline \multicolumn{5}{|c|}{ Inter-stage period flowering - grain formation } \\
\hline \multirow{3}{*}{ Without irrigation } & Without fertilizers & 620 & 609 & 603 \\
\hline & Calculated dose & 680 & 647 & 632 \\
\hline & Recommended $\mathrm{N}_{120} \mathrm{P}_{90}$ & 692 & 654 & 646 \\
\hline \multirow{3}{*}{$\begin{array}{c}\text { Biologically } \\
\text { optimal 70-80-70\% } \\
\text { FC in the soil layer } \\
0-50 \mathrm{~cm}\end{array}$} & Without fertilizers & 732 & 679 & 666 \\
\hline & Calculated dose & 792 & 709 & 698 \\
\hline & Recommended $\mathrm{N}_{120} \mathrm{P}_{90}$ & 804 & 767 & 718 \\
\hline \multirow{3}{*}{$\begin{array}{l}\text { Water-saving } 70- \\
70-70 \% \text { FC in the } \\
\text { soil layer } 0-50 \mathrm{~cm}\end{array}$} & Without fertilizers & 731 & 678 & 664 \\
\hline & Calculated dose & 791 & 708 & 693 \\
\hline & Recommended $\mathrm{N}_{120} \mathrm{P}_{90}$ & 803 & 765 & 707 \\
\hline
\end{tabular}


Table 1 (continuance)

\begin{tabular}{|c|c|c|c|c|}
\hline \multirow{3}{*}{$\begin{array}{l}\text { Soil-protective } 70- \\
70-70 \% \text { FC in the } \\
\text { soil layer } 0-30 \mathrm{~cm}\end{array}$} & Without fertilizers & 728 & 676 & 662 \\
\hline & Calculated dose & 789 & 735 & 681 \\
\hline & Recommended $\mathrm{N}_{120} \mathrm{P}_{90}$ & 800 & 763 & 704 \\
\hline \multicolumn{5}{|c|}{ Inter-stage period milk and milk-wax ripeness of grain } \\
\hline \multirow{3}{*}{ Without irrigation } & Without fertilizers & 754 & 720 & 701 \\
\hline & Calculated dose & 778 & 746 & 726 \\
\hline & Recommended $\mathrm{N}_{120} \mathrm{P}_{90}$ & 816 & 776 & 753 \\
\hline \multirow{3}{*}{$\begin{array}{c}\text { Biologically } \\
\text { optimal } 70-80-70 \% \\
\text { FC in the soil layer } \\
0-50 \mathrm{~cm}\end{array}$} & Without fertilizers & 1087 & 908 & 839 \\
\hline & Calculated dose & 1113 & 954 & 871 \\
\hline & Recommended $\mathrm{N}_{120} \mathrm{P}_{90}$ & 1118 & 1015 & 894 \\
\hline \multirow{3}{*}{$\begin{array}{c}\text { Water-saving } \\
70-70-70 \% \text { FC } \\
\text { in the soil layer 0- } \\
50 \mathrm{~cm}\end{array}$} & Without fertilizers & 1042 & 935 & 832 \\
\hline & Calculated dose & 1060 & 955 & 856 \\
\hline & Recommended $\mathrm{N}_{120} \mathrm{P}_{90}$ & 1085 & 996 & 869 \\
\hline \multirow{3}{*}{$\begin{array}{c}\text { Soil-protective } \\
70-70-70 \% \text { FC } \\
\text { in the soil layer 0- } \\
30 \mathrm{~cm}\end{array}$} & Without fertilizers & 1032 & 930 & 760 \\
\hline & Calculated dose & 1069 & 940 & 831 \\
\hline & Recommended $\mathrm{N}_{120} \mathrm{P}_{90}$ & 1076 & 975 & 840 \\
\hline \multicolumn{5}{|c|}{ Inter-stage period wax-full ripeness of grain } \\
\hline \multirow{3}{*}{ Without irrigation } & Without fertilizers & 716 & 672 & 613 \\
\hline & Calculated dose & 741 & 678 & 648 \\
\hline & Recommended $\mathrm{N}_{120} \mathrm{P}_{90}$ & 748 & 678 & 665 \\
\hline \multirow{3}{*}{$\begin{array}{c}\text { Biologically } \\
\text { optimal 70-80-70\% } \\
\text { FC in the soil layer } \\
0-50 \mathrm{~cm} \\
\end{array}$} & Without fertilizers & 999 & 820 & 751 \\
\hline & Calculated dose & 1025 & 866 & 783 \\
\hline & Recommended $\mathrm{N}_{120} \mathrm{P}_{90}$ & 1030 & 927 & 806 \\
\hline \multirow{3}{*}{$\begin{array}{c}\text { Water-saving } \\
\text { 70-70-70\% FC in } \\
\text { the soil layer 0-50 } \\
\text { cm }\end{array}$} & Without fertilizers & 954 & 847 & 744 \\
\hline & Calculated dose & 972 & 867 & 768 \\
\hline & Recommended $\mathrm{N}_{120} \mathrm{P}_{90}$ & 997 & 908 & 781 \\
\hline \multirow{3}{*}{$\begin{array}{c}\text { Soil-protective } \\
70-70-70 \% \text { FC } \\
\text { in the soil layer } \\
0-30 \mathrm{~cm}\end{array}$} & Without fertilizers & 944 & 842 & 672 \\
\hline & Calculated dose & 981 & 852 & 743 \\
\hline & Recommended $\mathrm{N}_{120} \mathrm{P}_{90}$ & 988 & 887 & 752 \\
\hline
\end{tabular}

The maximum amount of crude corn biomass was fixed at the stage of milk-wax ripeness of grain, regardless the influence of factors studied. But the greatest manifestation to the increase of crude biomass of corn accumulation was contributed by the improvement of conditions of humidification of plants through vegetative watering. 
A significant amount of crude corn biomass was fixed at the stage of milk grain ripeness, and in the variants with the biologically optimum regime of irrigation $70-80-70 \% \mathrm{FC}$ in the soil layer $0-50 \mathrm{~cm}$ its figure was maximal and averaged by the factors to $978 \mathrm{~g}$. With regard to water-saving and soilprotective regimes, their values were close to the optimum and, accordingly, were 959 and $939 \mathrm{~g}$. Comparing with non-irrigated variants, where the value of the surface crude biomass was $752 \mathrm{~g}$, we found that irrigation provided an increase in biomass by 27.5-30\%. Application of mineral fertilizers positively influenced on the indicators of accumulation of green mass by corn plants. The maximum difference between the variants without fertilizers and plots with the application of $\mathrm{N}_{120} \mathrm{P}_{90}$ and calculated dose was observed at the stage of milk ripeness and averaged to $3.4-5.5 \%$.

The increase in plant density, on the contrary, negatively affected on the raw weight of a plant. Thus, in the period of milk ripeness of grain the increase in the density of crops from 40 to 60 and 80 thousand/ha led to the reduction of raw plant weight by 9.8 and $18.8 \%$, respectively.

Table 2

Dynamics of biomass accumulation at the milk ripeness stage, $t / h a$

\begin{tabular}{|c|c|c|c|c|c|c|}
\hline \multirow{2}{*}{$\begin{array}{l}\text { Conditions of } \\
\text { humidification }\end{array}$} & \multirow{2}{*}{$\begin{array}{l}\text { Mineral nutrition } \\
\text { background }\end{array}$} & \multicolumn{3}{|c|}{$\begin{array}{c}\text { Density of } \\
\text { plants, thousand/ha }\end{array}$} & \multicolumn{2}{|c|}{$\begin{array}{l}\text { Average by } \\
\text { the factors }\end{array}$} \\
\hline & & 40 & 60 & 80 & A & B \\
\hline \multirow{3}{*}{$\begin{array}{l}\text { Without } \\
\text { irrigation }\end{array}$} & Without fertilizers & 30.2 & 43.2 & 56.1 & \multirow{3}{*}{12.4} & 15.2 \\
\hline & Calculated dose & 31.1 & 44.8 & 58.1 & & 16.6 \\
\hline & $\begin{array}{c}\text { Recommended } \\
\mathrm{N}_{120} \mathrm{P}_{90}\end{array}$ & 32.6 & 46.6 & 60.2 & & 17.2 \\
\hline \multirow{3}{*}{$\begin{array}{c}\text { Biologically } \\
\text { optimal 70-80- } \\
70 \% \text { FC in the } \\
\text { soil layer } 0-50 \\
\text { cm }\end{array}$} & Without fertilizers & 43.5 & 54.5 & 67.1 & \multirow{3}{*}{18.2} & \\
\hline & Calculated dose & 44.5 & 57.2 & 69.7 & & \\
\hline & $\begin{array}{c}\text { Recommended } \\
\mathrm{N}_{120} \mathrm{P}_{90}\end{array}$ & 44.7 & 60.9 & 71.5 & & \\
\hline \multirow{3}{*}{$\begin{array}{c}\text { Water-saving } \\
70-70-70 \% \text { FC } \\
\text { in the soil layer } \\
0-50 \mathrm{~cm}\end{array}$} & Without fertilizers & 41.7 & 56.1 & 66.6 & \multirow{3}{*}{17.5} & \\
\hline & Calculated dose & 42.4 & 57.3 & 68.5 & & \\
\hline & $\begin{array}{c}\text { Recommended } \\
\mathrm{N}_{120} \mathrm{P}_{90} \\
\end{array}$ & 43.4 & 59.8 & 69.5 & & \\
\hline \multirow{3}{*}{$\begin{array}{c}\text { Soil-protective } \\
70-70-70 \% \text { FC } \\
\text { in the soil layer } \\
0-30 \mathrm{~cm}\end{array}$} & Without fertilizers & 41.3 & 55.8 & 60.8 & \multirow{3}{*}{17.2} & \\
\hline & Calculated dose & 42.8 & 56.4 & 66.5 & & \\
\hline & $\begin{array}{l}\text { Recommended } \\
\mathrm{N}_{120} \mathrm{P}_{90}\end{array}$ & 43.0 & 58.5 & 67.2 & & \\
\hline \multicolumn{2}{|c|}{ Average by the factor $\mathrm{C}$} & 11.7 & 16.6 & 20.7 & & \\
\hline \multicolumn{7}{|c|}{$\mathrm{LSD}_{05}$, t/ha: factor A - 0.8; factor B - 1.4; factor C -0.9} \\
\hline
\end{tabular}


At the full ripeness of grain there was a decrease in the productivity of crude biomass of plants in all the variants and in all the years of the study. This is because plastic substances move from the vegetative mass to the grain.

The effectiveness of irrigation, application of mineral fertilizers and increase in the density of corn are also confirmed by the productivity of crude biomass per hectare.

Accumulation of vegetative mass per 1 hectare of crops, on average by the studied factors, during the growing season of corn was rather uneven and depended mainly on the stages of growth and development of the plants. However, the maximum values it reached at the stage of milk ripeness of grain (Table 2).

Analyzing the data of the study, the dynamics of accumulation of raw vegetative mass of the plants concerning irrigation regimes and mineral nutrition effects was like the dynamics of biomass indices per plant. That is, the improvement of water and nutritive regimes of corn plants positively affected the yield of green mass per 1 hectare of the crops, either as per each plant. However, the increase in density of corn plants, in this case, showed positive effect on the weight of surface biomass per hectare of the crops.

Thus, the value of the crude biomass accumulation at the use of irrigation regimes changed in the range from 54.7 to $57.1 \mathrm{t} / \mathrm{ha}$, this is by 22.2-27.5\% bigger than at the non-irrigated variant.

Mineral nutrition increased the green mass yield of corn plants by $1.9-3.4 \mathrm{t} / \mathrm{ha}$, or by $3.6-6.7 \%$.

Thickening of the crops resulted in the increase in raw biomass per hectare. Thus, at the density of 40 thousand/ha weight of surface biomass was, on average by the factor, $40.1 \mathrm{t} / \mathrm{ha}$, at 60 thousand/ha $-54.25 \mathrm{t} / \mathrm{ha}$, that is by $35.3 \%$ bigger than the previous value. The maximum value of vegetative mass was obtained at the density of plants of 80 thousand/ha, and averaged to $65.15 \mathrm{t} / \mathrm{ha}$, that is by $62.5 \%$ bigger than at the density of 40 thousand/ha.

\section{Influence of conditions of humidification, background of mineral nutrition and density of plants on the indicators of accumulation of dry matter in the plants of corn}

The dynamics of accumulation of dry matter is mostly determined by the conditions of water supply, mineral nutrition and density of plants.

At the beginning of the growing season, the process of accumulation of dry biomass was slow (Table 3). Further, and especially during the intensive formation of leaf apparatus system, the daily gain of dry matter has increased significantly. So, if at the stage of 7 leaves its weight was only 19.0-21.7 g per 1 plant, then in the period of 11 leaves this figure drastically increased and was, on average by the studied factors, 41.7-68.8 g per plant. 
Table 3

Dynamics of accumulation of dry biomass by the plants of corn, $g$ per plant

\begin{tabular}{|c|c|c|c|c|}
\hline \multirow{2}{*}{$\begin{array}{c}\text { Conditions of } \\
\text { humidification }\end{array}$} & \multirow{2}{*}{$\begin{array}{l}\text { Mineral nutrition } \\
\text { background }\end{array}$} & \multicolumn{3}{|c|}{$\begin{array}{c}\text { Density of plants, thousand } \\
\text { pcs/ha }\end{array}$} \\
\hline & & 40 & 60 & 80 \\
\hline \multicolumn{5}{|c|}{ Inter-stage period 6-7 leaves } \\
\hline \multirow{3}{*}{ Without irrigation } & Without fertilizers & 20.9 & 20.4 & 20.0 \\
\hline & Calculated dose & 23.7 & 22.6 & 22.0 \\
\hline & Recommended $\mathrm{N}_{120} \mathrm{P}_{90}$ & 24.6 & 23.7 & 23.1 \\
\hline \multicolumn{5}{|c|}{ Inter-stage period 9-11 leaves } \\
\hline \multirow{3}{*}{ Without irrigation } & Without fertilizers & 45.1 & 43.7 & 41.7 \\
\hline & Calculated dose & 51.0 & 49.9 & 47.3 \\
\hline & Recommended $\mathrm{N}_{120} \mathrm{P}_{90}$ & 52.9 & 51.0 & 47.4 \\
\hline \multirow{3}{*}{$\begin{array}{l}\text { Biologically optimal } \\
70-80-70 \% \text { FC in the } \\
\text { soil layer } 0-50 \mathrm{~cm}\end{array}$} & Without fertilizers & 61.0 & 59.6 & 57.6 \\
\hline & Calculated dose & 66.9 & 65.8 & 63.2 \\
\hline & Recommended $\mathrm{N}_{120} \mathrm{P}_{90}$ & 68.8 & 66.9 & 63.3 \\
\hline \multirow{3}{*}{$\begin{array}{l}\text { Water-saving 70-70- } \\
70 \% \text { FC in the soil } \\
\text { layer 0-50 cm }\end{array}$} & Without fertilizers & 57.7 & 56.3 & 54.3 \\
\hline & Calculated dose & 63.6 & 62.5 & 59.9 \\
\hline & Recommended $\mathrm{N}_{120} \mathrm{P}_{90}$ & 65.5 & 63.6 & 60.0 \\
\hline \multirow{3}{*}{$\begin{array}{l}\text { Soil-protective 70-70- } \\
70 \% \text { FC in the soil } \\
\text { layer } 0-30 \mathrm{~cm}\end{array}$} & Without fertilizers & 56.0 & 54.6 & 52.6 \\
\hline & Calculated dose & 61.9 & 60.8 & 58.2 \\
\hline & Recommended $\mathrm{N}_{120} \mathrm{P}_{90}$ & 63.8 & 61.9 & 58.3 \\
\hline \multicolumn{5}{|c|}{ Inter-stage period flowering-grain formation } \\
\hline \multirow{3}{*}{ Without irrigation } & Without fertilizers & 103.0 & 86.7 & 76.4 \\
\hline & Calculated dose & 123.9 & 107.8 & 88.8 \\
\hline & Recommended $\mathrm{N}_{120} \mathrm{P}_{90}$ & 134.7 & 125.6 & 99.9 \\
\hline \multirow{3}{*}{$\begin{array}{l}\text { Biologically optimal } \\
70-80-70 \% \text { FC in the } \\
\text { soil layer } 0-50 \mathrm{~cm}\end{array}$} & Without fertilizers & 129.0 & 112.7 & 102.4 \\
\hline & Calculated dose & 149.9 & 133.8 & 114.8 \\
\hline & Recommended $\mathrm{N}_{120} \mathrm{P}_{90}$ & 160.7 & 151.6 & 125.9 \\
\hline \multirow{3}{*}{$\begin{array}{c}\text { Water-saving } \\
70-70-70 \% \text { FC in the } \\
\text { soil layer } 0-50 \mathrm{~cm}\end{array}$} & Without fertilizers & 123.7 & 107.4 & 97.1 \\
\hline & Calculated dose & 144.6 & 128.5 & 109.5 \\
\hline & Recommended $\mathrm{N}_{120} \mathrm{P}_{90}$ & 155.4 & 146.3 & 120.6 \\
\hline \multirow{3}{*}{$\begin{array}{l}\text { Soil protection } \\
70-70-70 \% \text { FC in the } \\
\text { soil layer } 0-30 \mathrm{~cm}\end{array}$} & Without fertilizers & 122.1 & 105.8 & 95.5 \\
\hline & Calculated dose & 143.0 & 126.9 & 107.9 \\
\hline & Recommended $\mathrm{N}_{120} \mathrm{P}_{90}$ & 153.8 & 144.7 & 119.0 \\
\hline
\end{tabular}


Table 3 (continuance)

\begin{tabular}{|c|c|c|c|c|}
\hline \multicolumn{5}{|c|}{ Inter-stage period milk and milk-wax maturity of grain } \\
\hline \multirow{3}{*}{ Without irrigation } & Without fertilizers & 130.5 & 114.2 & 103.9 \\
\hline & Calculated dose & 151.4 & 135.3 & 116.3 \\
\hline & Recommended $\mathrm{N}_{120} \mathrm{P}_{90}$ & 162.2 & 153.1 & 127.4 \\
\hline \multirow{3}{*}{$\begin{array}{l}\text { Biologically optimal } \\
70-80-70 \% \text { FC in the } \\
\text { soil layer } 0-50 \mathrm{~cm}\end{array}$} & Without fertilizers & 186.5 & 170.2 & 159.9 \\
\hline & Calculated dose & 207.4 & 191.3 & 172.3 \\
\hline & Recommended $\mathrm{N}_{120} \mathrm{P}_{90}$ & 218.2 & 209.1 & 183.4 \\
\hline \multirow{3}{*}{$\begin{array}{c}\text { Water-saving } \\
70-70-70 \% \text { FC in the } \\
\text { soil layer } 0-50 \mathrm{~cm}\end{array}$} & Without fertilizers & 181.2 & 164.9 & 154.6 \\
\hline & Calculated dose & 202.1 & 186.0 & 167.0 \\
\hline & Recommended $\mathrm{N}_{120} \mathrm{P}_{90}$ & 212.9 & 203.8 & 178.1 \\
\hline \multirow{3}{*}{$\begin{array}{l}\text { Soil protection } \\
70-70-70 \% \text { FC in the } \\
\text { soil layer } 0-30 \mathrm{~cm}\end{array}$} & Without fertilizers & 179.6 & 163.3 & 153.0 \\
\hline & Calculated dose & 200.5 & 184.4 & 165.4 \\
\hline & Recommended $\mathrm{N}_{120} \mathrm{P}_{90}$ & 211.3 & 202.2 & 176.5 \\
\hline \multicolumn{5}{|c|}{ Inter-stage period wax-full ripeness of grain } \\
\hline \multirow{3}{*}{ Without irrigation } & Without fertilizers & 208.5 & 192.2 & 181.9 \\
\hline & Calculated dose & 229.4 & 213.3 & 194.3 \\
\hline & Recommended $\mathrm{N}_{120} \mathrm{P}_{90}$ & 240.2 & 231.1 & 205.4 \\
\hline \multirow{3}{*}{$\begin{array}{l}\text { Biologically optimal } \\
70-80-70 \% \mathrm{FC} \text { in the } \\
\text { soil layer } 0-50 \mathrm{~cm}\end{array}$} & Without fertilizers & 299.5 & 278.2 & 267.9 \\
\hline & Calculated dose & 339.4 & 320.3 & 290.3 \\
\hline & Recommended $\mathrm{N}_{120} \mathrm{P}_{90}$ & 345.2 & 328.1 & 300.4 \\
\hline \multirow{3}{*}{$\begin{array}{c}\text { Water-saving } \\
70-70-70 \% \text { FC in the } \\
\text { soil layer } 0-50 \mathrm{~cm}\end{array}$} & Without fertilizers & 289.2 & 272.9 & 262.6 \\
\hline & Calculated dose & 315.1 & 300.0 & 285.0 \\
\hline & Recommended $\mathrm{N}_{120} \mathrm{P}_{90}$ & 320.9 & 311.8 & 296.1 \\
\hline \multirow{3}{*}{$\begin{array}{l}\text { Soil protection } \\
70-70-70 \% \mathrm{FC} \text { in the } \\
\text { soil layer } 0-30 \mathrm{~cm}\end{array}$} & Without fertilizers & 287.6 & 271.3 & 261.0 \\
\hline & Calculated dose & 308.5 & 292.4 & 273.4 \\
\hline & Recommended $\mathrm{N}_{120} \mathrm{P}_{90}$ & 319.3 & 310.2 & 284.5 \\
\hline
\end{tabular}

The maximum level the dry mass indicators, in contrast to the raw surface biomass, corn plants have reached at the end of the growing season, in the inter-stage period from wax to full ripeness of grain.

The highest value of dry mass of corn was fixed in the variants with the biologically optimal irrigation mode $70-80-70 \%$ FC in the soil layer of 0 $50 \mathrm{~cm}$, on average by the factors, $-307.7 \mathrm{~g}$ per plant. The variants with watersaving and soil-protective regimes are slightly different, their productivity was, respectively, 289.8 and $294.8 \mathrm{~g}$.

Comparing with the variants without irrigation, the amounts of dry mass of which were 181.9-240.2 g, it was determined that irrigation provided the mass increase by 37.5-46.0\% depending on the regime of irrigation. 
The use of fertilizers positively affected the increase in weight of the dry mass of corn plants. Unlike the plots without fertilizers, the variants with the application of $\mathrm{N}_{120} \mathrm{P}_{90}$ and calculated doses provided the increase, on average by the factors, by 9.4 and $13.7 \%$, respectively.

Plant density, on the contrary, negatively affected the dry weight per plant. Thus, during the wax ripeness of grain the increase in the density of crops from 40 to 60 thousand/ha led to the reduction of the dry mass per plant by $5.2 \%$, and to 80 thousand/ha - by $11.4 \%$, respectively. However, the recalculation per hectare showed that thickening of corn plants positively affected the weight of the surface dry mass. That is, at the density of 40 thousand/ha at the stage of wax ripeness the weight of surface dry mass was, on average by the factor, $11.7 \mathrm{t} / \mathrm{ha}$, and with the increase in density to 60 , 80 thousand/ha - 16.6 and 20.7 t/ha, respectively, or by 42.2 and $77.2 \%$ bigger than at the previous values.

\section{Dynamics of growth of leaf surface}

An important influence on quantitative and qualitative indices of productivity formation are physical and physiological processes that transform solar energy into organic matter in the system atmosphere - leaf plant - agrocenosis. The intensity of this process depends significantly on the characteristics and spectral composition of solar radiation, the energy balance between the absorbed energy and the expenses on photosynthesis, transpiration, heat and moisture exchange, availability of nutrients and easily accessible moisture, etc ${ }^{9}$. To optimize productive processes and to form the maximum possible corn yield a great value has the size of the plant leaf, which accumulates solar radiation during photosynthesis and provides the creation of organic matter ${ }^{10}$.

Researches studied the reaction of corn plants on irrigation regimes, application of mineral fertilizers and density of plants by defining their indices of photosynthetic activity. The area of leaf surface of the crop was rather volatile and depended both on weather conditions during the years of the researches and on the investigated factors (Table 4).

At the beginning of the vegetative period (6-7 leaves), the area of leaf apparatus, on average for the years of the study, in all the plots fluctuated within 4.8-10.3 thousand $\mathrm{m}^{2} / \mathrm{ha}$. Since in this period the leaf apparatus was formed only under natural humidification, there was no significant difference between the variants. At the same time, the area of the assimilation apparatus per plant in this period was the minimum $-1.14-1.38 \mathrm{~cm}^{2}$.

\footnotetext{
${ }^{9}$ Системи землеробства на зрошуваних землях України / За наук. ред. Р.А. Вожегової. К.: Аграрн. наука, 2014. 360 с.

${ }_{10}$ Андрієнко А.Л. Основні заходи сортової агротехніки гібридів кукурудзи різних груп стиглості в північному Степу України: автореф. дис. на здобуття наук. ступеня канд. с.-г. наук: спец. 06.01 .09 "Рослинництво" / А.Л. Андрієнко. Дніпропетровськ, 2004. 19 с.
} 
Leaf area of the plants of corn per $1 \mathrm{ha}$, thousand $\mathrm{m}^{2}$

(the average for 2009-2018)

\begin{tabular}{|c|c|c|c|c|}
\hline \multirow{2}{*}{$\begin{array}{c}\text { Conditions of } \\
\text { humidification }\end{array}$} & \multirow{2}{*}{$\begin{array}{l}\text { Mineral nutrition } \\
\text { background }\end{array}$} & \multicolumn{3}{|c|}{$\begin{array}{l}\text { Density of plants, thousand } \\
\text { pcs/ha }\end{array}$} \\
\hline & & 40 & 60 & 80 \\
\hline \multicolumn{5}{|c|}{ Inter-stage period 6-7 leaves } \\
\hline \multirow{3}{*}{ Without irrigation } & Without fertilizers & 4.8 & 6.9 & 9.3 \\
\hline & Calculated dose & 5.3 & 7.3 & 9.6 \\
\hline & Recommended $\mathrm{N}_{120} \mathrm{P}_{90}$ & 5.5 & 7.8 & 10.3 \\
\hline \multicolumn{5}{|c|}{ Inter-stage period 9-11 leaves } \\
\hline \multirow{3}{*}{ Without irrigation } & Without fertilizers & 16.7 & 22.1 & 24.2 \\
\hline & Calculated dose & 18.3 & 23.0 & 26.3 \\
\hline & Recommended $\mathrm{N}_{120} \mathrm{P}_{90}$ & 19.5 & 25.2 & 27.2 \\
\hline \multirow{3}{*}{$\begin{array}{l}\text { Biologically optimal } \\
70-80-70 \% \text { FC in the } \\
\text { soil layer } 0-50 \mathrm{~cm}\end{array}$} & Without fertilizers & 22.4 & 28.5 & 31.7 \\
\hline & Calculated dose & 23.3 & 30.0 & 32.8 \\
\hline & Recommended $\mathrm{N}_{120} \mathrm{P}_{90}$ & 24.7 & 31.2 & 33.1 \\
\hline \multirow{3}{*}{$\begin{array}{l}\text { Water-saving } \\
70-70-70 \% \text { FC in the } \\
\text { soil layer } 0-50 \mathrm{~cm}\end{array}$} & Without fertilizers & 18.2 & 24.7 & 30.0 \\
\hline & Calculated dose & 19.8 & 25.2 & 31.7 \\
\hline & Recommended $\mathrm{N}_{120} \mathrm{P}_{90}$ & 21.3 & 28.8 & 32.4 \\
\hline \multirow{3}{*}{$\begin{array}{l}\text { Soil-protective } \\
70-70-70 \% \text { FC in the } \\
\text { soil layer } 0-30 \mathrm{~cm}\end{array}$} & Without fertilizers & 17.9 & 23.5 & 29.2 \\
\hline & Calculated dose & 19.1 & 24.9 & 30.8 \\
\hline & Recommended $\mathrm{N}_{120} \mathrm{P}_{90}$ & 20.9 & 25.5 & 31.0 \\
\hline \multicolumn{5}{|c|}{ Inter-stage period flowering - grain formation } \\
\hline \multirow{3}{*}{ Without irrigation } & Without fertilizers & 20.8 & 25.9 & 27.6 \\
\hline & Calculated dose & 21.7 & 26.4 & 29.2 \\
\hline & Recommended $\mathrm{N}_{120} \mathrm{P}_{90}$ & 22.1 & 27.6 & 30.4 \\
\hline \multirow{3}{*}{$\begin{array}{c}\text { Biologically optimal } \\
70-80-70 \% \text { FC in the } \\
\text { soil layer } 0-50 \mathrm{~cm}\end{array}$} & Without fertilizers & 29.7 & 35.6 & 41.8 \\
\hline & Calculated dose & 31.9 & 37.8 & 45.9 \\
\hline & Recommended $\mathrm{N}_{120} \mathrm{P}_{90}$ & 33.2 & 38.1 & 47.3 \\
\hline \multirow{6}{*}{$\begin{array}{l}\text { Water-saving } \\
70-70-70 \% \text { FC in the } \\
\text { soil layer } 0-50 \mathrm{~cm}\end{array}$} & Without fertilizers & 24.3 & 29.0 & 36.2 \\
\hline & Calculated dose & 27.3 & 35.3 & 41.8 \\
\hline & Recommended $\mathrm{N}_{120} \mathrm{P}_{90}$ & 30.9 & 36.9 & 43.7 \\
\hline & Without fertilizers & 23.0 & 28.3 & 32.9 \\
\hline & Calculated dose & 25.5 & 33.5 & 40.6 \\
\hline & Recommended $\mathrm{N}_{120} \mathrm{P}_{90}$ & 28.8 & 34.8 & 42.5 \\
\hline
\end{tabular}


Table 4 (continuance)

\begin{tabular}{|c|c|c|c|c|}
\hline \multicolumn{5}{|c|}{ Inter-stage period milk and milk-wax ripeness of grain } \\
\hline \multirow{3}{*}{ Without irrigation } & Without fertilizers & 18.7 & 20.4 & 27.3 \\
\hline & Calculated dose & 19.1 & 21.7 & 28.1 \\
\hline & Recommended $\mathrm{N}_{120} \mathrm{P}_{90}$ & 20.1 & 22.8 & 28.9 \\
\hline \multirow{3}{*}{$\begin{array}{l}\text { Biologically optimal } \\
70-80-70 \% \text { FC in the } \\
\text { soil layer } 0-50 \mathrm{~cm}\end{array}$} & Without fertilizers & 22.0 & 27.9 & 34.8 \\
\hline & Calculated dose & 25.5 & 31.0 & 38.2 \\
\hline & Recommended $\mathrm{N}_{120} \mathrm{P}_{90}$ & 26.0 & 31.9 & 39.3 \\
\hline \multirow{3}{*}{$\begin{array}{l}\text { Water-saving } \\
70-70-70 \% \text { FC in the } \\
\text { soil layer } 0-50 \mathrm{~cm}\end{array}$} & Without fertilizers & 19.1 & 25.0 & 30.0 \\
\hline & Calculated dose & 23.6 & 28.9 & 32.0 \\
\hline & Recommended $\mathrm{N}_{120} \mathrm{P}_{90}$ & 24.4 & 30.9 & 34.2 \\
\hline \multirow{3}{*}{$\begin{array}{c}\text { Soil-protective } \\
70-70-70 \% \mathrm{FC} \text { in the } \\
\text { soil layer } 0-30 \mathrm{~cm}\end{array}$} & Without fertilizers & 18.8 & 24.2 & 29.1 \\
\hline & Calculated dose & 22.3 & 27.4 & 31.7 \\
\hline & Recommended $\mathrm{N}_{120} \mathrm{P}_{90}$ & 23.8 & 29.2 & 32.7 \\
\hline \multicolumn{5}{|c|}{ Inter-stage period wax-full ripeness of grain } \\
\hline \multirow{3}{*}{ Without irrigation } & Without fertilizers & 12.4 & 18.5 & 21.7 \\
\hline & Calculated dose & 13.9 & 19.6 & 22.3 \\
\hline & Recommended $\mathrm{N}_{120} \mathrm{P}_{90}$ & 14.7 & 20.1 & 22.8 \\
\hline \multirow{3}{*}{$\begin{array}{l}\text { Biologically optimal } \\
70-80-70 \% \text { FC in the } \\
\text { soil layer } 0-50 \mathrm{~cm}\end{array}$} & Without fertilizers & 14.4 & 20.5 & 27.4 \\
\hline & Calculated dose & 17.0 & 23.5 & 30.8 \\
\hline & Recommended $\mathrm{N}_{120} \mathrm{P}_{90}$ & 17.8 & 23.8 & 31.9 \\
\hline \multirow{3}{*}{$\begin{array}{c}\text { Water-saving } \\
70-70-70 \% \mathrm{FC} \text { in the } \\
\text { soil layer } 0-50 \mathrm{~cm}\end{array}$} & Without fertilizers & 14.6 & 19.6 & 24.0 \\
\hline & Calculated dose & 16.3 & 22.6 & 25.9 \\
\hline & Recommended $\mathrm{N}_{120} \mathrm{P}_{90}$ & 16.9 & 23.0 & 26.6 \\
\hline \multirow{3}{*}{$\begin{array}{l}\text { Soil-protective } \\
70-70-70 \% \mathrm{FC} \text { in the } \\
\text { soil layer } 0-30 \mathrm{~cm}\end{array}$} & Without fertilizers & 13.0 & 19.0 & 22.6 \\
\hline & Calculated dose & 14.3 & 21.1 & 23.3 \\
\hline & Recommended $\mathrm{N}_{120} \mathrm{P}_{90}$ & 15.1 & 22.0 & 24.6 \\
\hline
\end{tabular}

After the first vegetative waterings (10-11 leaves) the indicators of the leaves' area were considerably increased in comparison with the previous stage. The highest values were achieved in the irrigated plants, comparatively to the variants without irrigation, regardless on the plant density and background of mineral nutrition. Thus, on the plots without irrigation the leaf area reached $22.5 \mathrm{~m}^{2} /$ ha, whereas in the variants with the biologically optimal regime of $70-80-70 \% \mathrm{FC}$ in the soil layer $0-50 \mathrm{~cm}$, it was $28.6 \mathrm{~m}^{2} / \mathrm{ha}$, at the water-saving regime $(70-70-70 \% \mathrm{FC}$ in the soil layer $0-50 \mathrm{~cm})-25.8 \mathrm{~m}^{2} / \mathrm{ha}$, and at the soil-protective one $(70-70-70 \%$ FC in the soil layer $0-30 \mathrm{~cm})-$ $24.8 \mathrm{~m}^{2} /$ ha. Therefore, irrigation provided an increase in the leaf apparatus area by $10.0-27.3 \%$. 
Application of mineral fertilizers, in contrast to the unfertilized plots, provided the increase in the area of the assimilation apparatus only by $1.6-2.3 \mathrm{~m}^{2} / \mathrm{ha}$. A little more increase of this indicator was provided by thickening of the crops from 40 to 60 and 80 thousand/ha, and it was 5.9-9.9 $\mathrm{m}^{2} / \mathrm{ha}$, or $29.1-48.9 \%$, depending on the variant of the experiment.

It was established that the maximum development of the leaf area is reached at the stage of flowering on all the studied variants. However, there is a significant difference between the influence of the studied factors.

The largest area of the leaves of corn plants averaged to 47.3 thousand $\mathrm{m}^{2} / \mathrm{ha}$ at the biologically optimal irrigation regime with the application of the recommended norm of fertilizer $\mathrm{N}_{120} \mathrm{P}_{90}$ and the density of plants 80 thousand/ha, and the smallest one was in the same period on the variant without irrigation, without fertilizers at the density of 40 thousand/ha, and it averaged to 20.8 thousand $\mathrm{m}^{2} / \mathrm{ha}$.

In the inter-stage flowering-grain formation the area of leaf apparatus per plant reached its peak and was 8.3 thousand $\mathrm{cm}^{2}$ on the above-mentioned variants, but at the density of 40 thousand/ha. The smallest value was fixed on the plots without irrigation, no fertilizers applied at the density of 80 thousand/ha -3.45 thousand $\mathrm{cm}^{2}$, which is $58.4 \%$ less.

In the inter-stage period of milk-milk-wax ripeness we observed the reduction in the area of leaf index on all the variants of the experiment due to the death of the lower leaves. This process in the variants with vegetative irrigation was slower than on the plots without irrigation.

Observing the growth and development of corn plants we found out that the average daily increase in the area of the assimilation surface reached its maximum in the inter-stage period from 7 leaves to 11 leaves and fluctuated within $0.85-1.48$ thousand $\mathrm{m}^{2} /$ day. Further the tendency to gradual reduction in this indicator with a critical decrease in the end of vegetation in all the studied variants was observed.

\section{Net productivity of photosynthesis and photosynthetic potential of corn plants}

In the field conditions the volume of corn yield under the improved water supply and mineral nutrition and the change in plant density depends mainly on the tempo of formation and the size of the photosynthetic apparatus and the intensity and duration of its work.

Photosynthetic potential accumulates solar energy in the process of photosynthesis and provides the creation of organic matter, which is essential for the accumulation of biomass. This parameter can serve as an indicator of potential of a particular crop and it significantly changes under the influence of soil-ecological, technological conditions and genetic features of a hybrid. The study of morpho-physiological indicators of corn hybrids can 
provide specific recommendations for the opening of reserved hybrids ${ }^{11}$ potential under specific conditions.

According to many scientists, one of the important indicators, which reflects the effectiveness of agro-technical activities of cultivation, is the pure productivity of plant photosynthesis in corn. The value of which ranges from 2 to $25 \mathrm{~g} / \mathrm{m}^{2}$ per day, and this figure reaches the maximum in the inter-stage period from 15 leaves to the beginning of grain ${ }^{12}$ formation.

The performed calculations indicate that on the average for 2009-2018 the values of the net performance of photosynthesis in corn crops has significantly changed by the stages of growth and development and strongly depended on the conditions of moisture supply. Thus, under different conditions of humidification at the nutritive background of $\mathrm{N}_{120} \mathrm{P}_{90}$ and the density of plants 80 thousand/ha this figure had the following values.

It was determined that in the initial stages of the plant growth and development (inter-stage 7-11 leaves), the net the productivity of photosynthesis was not great $-3.3 \mathrm{~g} / \mathrm{m}^{2}$ per day but did not depend on the studied factors. Significant difference between the variants of natural and artificial humidification was observed in the inter-stage of 11 leavesflowering, when at the variant without irrigation this figure did not exceed $7.5 \mathrm{~g} / \mathrm{m}^{2}$ per day, and in the variant with irrigation regime $70-80-70 \% \mathrm{FC}$ in the soil layer $0-50 \mathrm{~cm}$ it increased almost 1.5 times to $11.4 \mathrm{~g} / \mathrm{m}^{2}$ per day. At the irrigation with pre-watering threshold of $70 \%$ FC in the soil layer $0-50 \mathrm{~cm}$ throughout the vegetation, and $70-70-70 \% \mathrm{FC}$ in the soil layer $0-30 \mathrm{~cm}$, it should be noted that the indicator of net photosynthesis productivity slightly decreased in comparison with the biologically optimal irrigation regime, but considerably exceeded the non-irrigated variants, and it averaged to $9.5 \mathrm{~g} / \mathrm{m}^{2}$ per day (Table 5).

The maximum values of net photosynthesis were in the inter-stage period of flowering -grain formation on all the variants of humidification conditions. On the plots without irrigation, this figure did not exceed $10.4 \mathrm{~g} / \mathrm{m}^{2}$ per day, whereas under the use of water-saving and soil-protective regimes of irrigation it was 12.7 and $12.5 \mathrm{~g} / \mathrm{m}^{2}$ per day, respectively. The highest value in this inter-stage period was obtained at the irrigation regime $70-80-70 \% \mathrm{FC}$ in the soil layer $0-50 \mathrm{~cm}-13.2 \mathrm{~g} / \mathrm{m}^{2}$ per day.

${ }^{11}$ Дзюбецький Б.В., Писаренко В.А., Лавриненко Ю.О., Коковіхін С.В. Морфо-фізіологічні показники продукційного процесу та врожай насіння материнської форми гібрида кукурудзи Борисфен 433 МВ в умовах зрошення. Бюл. Інституту зернового господарства УАAH. 2000. № 14. С. 20-22.

12 Лавриненко Ю.О., Коковіхін С.В., Писаренко П.В.Екологічна мінливість показників темпів розвитку рослин кукурудзи. Таврійський науковий вісник: зб. наук. пр. Херсон: Айлант, 2005. Вип. 40. С. 46-55. 
Dynamics of net productivity of photosynthesis in corn crops depending on humidification conditions, $\mathrm{g} / \mathrm{m}^{2}$ per day (average for 2009-2018)

\begin{tabular}{|c|c|c|c|c|}
\hline \multirow[b]{2}{*}{$\begin{array}{l}\text { Inter-stage periods } \\
\text { of growth } \\
\text { and development }\end{array}$} & \multicolumn{4}{|c|}{ Conditions of humidification, \% FC } \\
\hline & 言哭 & $\begin{array}{c}70-80-70 \% \\
\text { FC in the } \\
\text { soil layer } \\
0-50 \mathrm{~cm}\end{array}$ & $\begin{array}{c}70-70-70 \% \\
\text { FC in the soil } \\
\text { layer } \\
0-50 \mathrm{~cm}\end{array}$ & $\begin{array}{c}70-70-70 \% \\
\text { FC in the } \\
\text { soil layer } \\
0-30 \mathrm{~cm}\end{array}$ \\
\hline 7 leaves -11 leaves & 3.3 & 3.3 & 3.3 & 3.3 \\
\hline 11 leaves - flowering & 7.5 & 11.4 & 9.5 & 9.5 \\
\hline $\begin{array}{l}\text { flowering - grain } \\
\text { formation }\end{array}$ & 10.4 & 13.2 & 12.7 & 12.5 \\
\hline $\begin{array}{l}\text { grain formation - milk } \\
\text { ripeness of grain }\end{array}$ & 6.2 & 9.9 & 8.1 & 7.1 \\
\hline $\begin{array}{l}\text { milk ripeness of grain - } \\
\text { wax ripeness of grain }\end{array}$ & 3.0 & 5.6 & 4.8 & 4.5 \\
\hline Average & 6.1 & 8.7 & 7.7 & 7.4 \\
\hline
\end{tabular}

Notes: mineral nutrition background $-N_{120} P_{90}$; density of plants 80 thousand pcs./ha.

Starting from the inter-stage period of formation - milk ripeness of grain, the indicators of net photosynthesis productivity are gradually decreasing and in the stage of wax ripeness it is in the non-irrigated conditions $3.0 \mathrm{~g} / \mathrm{m}^{2}$ per day. In the variant of the biologically optimal irrigation regime 5.6 , and at the water-saving and soil-protective ones -4.8 and $4.5 \mathrm{~g} / \mathrm{m}^{2}$ per day, respectively.

The volume of grain yield of corn is mainly determined by the development of the leaf apparatus of the plant and photosynthetic potential of the crops, which accumulates solar energy in the process of photosynthesis ${ }^{13}$. Photosynthetic potential is essential for the accumulation of biomass. This indicator can serve as an indicator of potential capacities of the crops of a particular type and significantly changes under the influence of soil, ecological, technological conditions, and hybrid's genotype. Therefore, the study of morpho-physiological parameters of corn plants can provide specific recommendations for opening of the reserved potential of plants under specific conditions ${ }^{14}$.

In our study, the photosynthetic potential during the vegetation period differed significantly in various conditions of humidification, application of mineral fertilizers and an increase in the density of plants.

${ }^{13}$ Ничипорович А.А. Основы фотосинтетической продуктивности растений. Современные проблемы фотосинтеза. М.: МГУ, 1973. С. 5-28.

${ }^{14}$ Надь Янош Кукурудза. Вінниця: ФОП Корзун Д.Ю., 2012. 580 с. 
The largest values were obtained at the variant with the biologically optimal regime of irrigation and was, on the average by the factor, 1743.9 thousand. $\mathrm{m}^{2} \times$ days. A little bit lower values were obtained in the variants with water-saving and soil-protective regimes - 1606.8 and 1584.5 thousand $\mathrm{m}^{2} \times$ days, respectively.

Consequently, the application of artificial humidification caused the increase of the photosynthetic potential of corn by $12.2-20.1 \%$, compared to the plots without irrigation.

The use of mineral fertilizers increased the photosynthetic potential by 8.7-11.8\%. Thus, application of recommended fertilizer dose of $\mathrm{N}_{120} \mathrm{P}_{90}$ This figure was 1665.7 thousand $\mathrm{m}^{2} \times$ days and the calculated dose for the planned yield -1609.9 thousand $\mathrm{m}^{2} \times$ days (Table 6 ).

Table 6

The photosynthetic potential of corn plants, thousand $\mathrm{m}^{2} \times$ days (average for 2009-2018)

\begin{tabular}{|c|c|c|c|c|c|c|}
\hline \multirow{2}{*}{$\begin{array}{r}\text { Conditions of } \\
\text { humidification }\end{array}$} & \multirow{2}{*}{$\begin{array}{l}\text { Mineral nutrition } \\
\text { background }\end{array}$} & \multicolumn{3}{|c|}{$\begin{array}{l}\text { Density of plants, } \\
\text { thousand/ha }\end{array}$} & \multicolumn{2}{|c|}{ Average } \\
\hline & & 40 & 60 & 80 & A & B \\
\hline \multirow{3}{*}{$\begin{array}{l}\text { Without } \\
\text { irrigation }\end{array}$} & Without fertilizers & 1068.4 & 1348.9 & 1570.1 & \multirow{3}{*}{1391.8} & 1469.8 \\
\hline & Calculated dose & 1117.1 & 1379.0 & 1682.6 & & 1609.9 \\
\hline & $\begin{array}{l}\text { Recommended } \\
\mathrm{N}_{120} \mathrm{P}_{90}\end{array}$ & 1149.7 & 1471.0 & 1739.4 & & 1665.7 \\
\hline \multirow{3}{*}{$\begin{array}{c}\text { Biologically } \\
\text { optimal } \\
70-80-70 \% \\
\text { FC in the soil } \\
\text { layer } \\
0-50 \mathrm{~cm}\end{array}$} & Without fertilizers & 1269.0 & 1543.6 & 2056.0 & \multirow{3}{*}{1743.9} & \\
\hline & Calculated dose & 1377.4 & 1784.9 & 2214.5 & & \\
\hline & $\begin{array}{c}\text { Recommended } \\
\mathrm{N}_{120} \mathrm{P}_{90} \\
\end{array}$ & 1408.0 & 1824.2 & 2218.1 & & \\
\hline \multirow{3}{*}{$\begin{array}{l}\text { Water-saving } \\
70-70-70 \% \\
\text { FC in the soil } \\
\text { layer } 0-50 \mathrm{~cm}\end{array}$} & Without fertilizers & 1128.7 & 1444.2 & 1808.5 & \multirow{3}{*}{1606.8} & \\
\hline & Calculated dose & 1245.0 & 1657.9 & 2000.8 & & \\
\hline & $\begin{array}{c}\text { Recommended } \\
\mathrm{N}_{120} \mathrm{P}_{90}\end{array}$ & 1332.1 & 1775.9 & 2068.5 & & \\
\hline \multirow{3}{*}{$\begin{array}{c}\text { Soil-protective } \\
70-70-70 \% \\
\text { FC in the soil } \\
\text { layer } \\
0-30 \mathrm{~cm} \\
\end{array}$} & Without fertilizers & 1251.5 & 1414.0 & 1734.7 & \multirow{3}{*}{1584.5} & \\
\hline & Calculated dose & 1296.8 & 1592.2 & 1970.3 & & \\
\hline & $\begin{array}{c}\text { Recommended } \\
\mathrm{N}_{120} \mathrm{P}_{90}\end{array}$ & 1316.8 & 1679.8 & 2004.7 & & \\
\hline \multicolumn{2}{|c|}{ Average by the factor $\mathrm{C}$} & 1246.7 & 1576.3 & 1922.3 & & \\
\hline
\end{tabular}


The photosynthetic potential increased with the increase in the density of corn plants. At thickening of the crops from 40 to $60-80$ thousand/ha, on the average by the studied factors, its indicators increased by $20.9-35.1 \%$, respectively.

The yield of conditioned seeds of corn hybrid Kros 221M at the plots of hybridization fluctuated by the years of the study within 3.89-9.10 t/ha depending on the regimes of irrigation, background of mineral nutrition and plant density (Table 7).

Table 7

The yield of conditioned seeds of corn at the plots of hybridization depending on the studied factors by the years of the study

\begin{tabular}{|c|c|c|c|c|c|c|}
\hline \multirow{3}{*}{$\begin{array}{l}\text { Conditions of } \\
\text { humidification, } \\
\text { (Factor A) }\end{array}$} & \multirow{3}{*}{$\begin{array}{l}\text { Mineral nutrition } \\
\text { background, } \\
\text { (Factor B) }\end{array}$} & \multirow{2}{*}{\multicolumn{3}{|c|}{$\begin{array}{l}\text { Density of plants, } \\
\text { thousand/ha } \\
\text { (Factor C) }\end{array}$}} & \multicolumn{2}{|c|}{$\begin{array}{l}\text { Average by } \\
\text { the factor }\end{array}$} \\
\hline & & & & & \multirow{2}{*}{ A } & \multirow{2}{*}{ B } \\
\hline & & 40 & 60 & 80 & & \\
\hline \multirow{3}{*}{$\begin{array}{l}\text { Without } \\
\text { irrigation }\end{array}$} & Without fertil & 3.89 & 4.11 & 4.61 & \multirow{3}{*}{4.66} & 5.77 \\
\hline & Calculated dose & 4.58 & 4.93 & 5.23 & & 7.07 \\
\hline & Recommended $\mathrm{N}_{120} \mathrm{P}_{90}$ & 4.63 & 4.81 & 5.11 & & 7.18 \\
\hline \multirow{3}{*}{$\begin{array}{c}\text { Biologically } \\
\text { optimal 70-80-70\% } \\
\text { FC in the soil layer } \\
0-50 \mathrm{~cm}\end{array}$} & Without fertilizers & 5.65 & 6.17 & 6.98 & \multirow{3}{*}{7.45} & \\
\hline & Calculated dose & 7.00 & 8.13 & 8.92 & & \\
\hline & Recommended $\mathrm{N}_{120} \mathrm{P}_{90}$ & 6.96 & 8.16 & 9.10 & & \\
\hline \multirow{3}{*}{$\begin{array}{c}\text { Water-saving } \\
70-70-70 \% \text { FC } \\
\text { in the soil layer } \\
0-50 \mathrm{~cm} \\
\end{array}$} & Without fertilizers & 5.68 & 6.26 & 6.99 & \multirow{3}{*}{6.61} & \\
\hline & Calculated dose & 6.68 & 7.66 & 8.44 & & \\
\hline & Recommended $\mathrm{N}_{120} \mathrm{P}_{90}$ & 6.79 & 7.85 & 8.73 & & \\
\hline \multirow{3}{*}{$\begin{array}{c}\text { Soil-protective } \\
70-70-70 \% \text { FC } \\
\text { in the soil layer } \\
0-30 \mathrm{~cm} \\
\end{array}$} & Without fertilizers & 5.59 & 6.50 & 6.81 & \multirow{3}{*}{7.35} & \\
\hline & Calculated dose & 6.76 & 7.97 & 8.51 & & \\
\hline & Recommended $\mathrm{N}_{120} \mathrm{P}_{90}$ & 6.82 & 8.23 & 8.93 & & \\
\hline \multicolumn{2}{|c|}{ Average by the factor $\mathrm{C}$} & 5.92 & 6.73 & 7.36 & & \\
\hline \multicolumn{6}{|c|}{$\mathrm{LSD}_{05}$, t/ha: Factor A - 0.37; Factor B - 0.41; Factor C - 0.39} & \\
\hline
\end{tabular}

The results of the study revealed that in the variants without irrigation the yield of conditioned seeds of the hybrid Kros 221M was 3.89-5.11 t/ha, depending on application of mineral fertilizers and density of plants. Application of vegetation watering contributed to the significant increase in grain yield of corn by 1.95-2.79 t/ha or $47.8-59.9 \%$.

Thus, at the biologically optimal regime of irrigation (70-80-70\% FC in the soil layer $0-50 \mathrm{~cm}$ ), the seed yield of $7.45 \mathrm{t} / \mathrm{ha}$ was obtained, on the average by the factor. Whereas in the variants with irrigation regime 
$70-70-70 \%$ FC in the soil layer $0-50 \mathrm{~cm}$ it was $6.61 \mathrm{t} / \mathrm{ha}$, and on the plots with irrigation regime $70-70-70 \% \mathrm{FC}$ in the soil layer 0-30 cm - 7.35 t/ha.

The use of fertilizers provided the increase in the yield of conditioned seeds of the hybrid Kros 221M, in comparison to the unfertilized variant, on the average by the factor, by 1.30-1.41 t/ha. Thickening of the crops on the plots of hybridization from 40 to 60 and 80 thousand/ha, on the average by the factor $\mathrm{C}$, contributed to the increase in the yield by $0.81-1.44 \mathrm{t} / \mathrm{ha}$.

\section{CONCLUSIONS}

The maximum development of the leaf area was reached during the flowering period on all the studied variants. The largest value it has acquired in the variant with the biologically optimal regime of irrigation at the application of the recommended dose $\mathrm{N}_{120} \mathrm{P}_{90}$ and the density of plants 80 thousand/ha, where it exceeded 47.0 thousand $\mathrm{m}^{2} / \mathrm{ha}$.

The photosynthetic potential during the vegetation period significantly differed by the studied variants. The largest values it acquired in the variant with the biologically optimal irrigation regime with the application of the recommended fertilizer dose $\mathrm{N}_{120} \mathrm{P}_{90}$ and the density of plants 80 thousand/ha.

The optimum humidification of corn crops provided obtaining of $7.45 \mathrm{t} / \mathrm{ha}$ of conditioned seeds. Irrigation at the pre-watering threshold of moisture $70-70-70 \%$ FC in $0-30$ and $0-50 \mathrm{~cm}$ soil layers reduced the yield, on average by the factor, by $0.10-0.84 \mathrm{t} / \mathrm{ha}$. The use of fertilizers provided the increase in the yield of corn seeds, in comparison with the unfertilized variant, on the average by the factor, by 1.30-1.41 t/ha. Thickening of the crops on the hybridization plots from 40 to 60 and 80 thousand/ha, on the average by the factor, contributed to the increase in the yield by $0.81-1.44 \mathrm{t} / \mathrm{ha}$, respectively.

\section{SUMMARY}

The goal of the study was to substantiate and improve the elements of the cultivation technology of the corn hybrid Kros 221M on the plots of hybridization in the irrigated conditions of the South of Ukraine.

The cultivation technology elements for corn seeds growing in the conditions of irrigation in the South of Ukraine were improved, thus reducing the expenditures for irrigation water and other resources on the obtaining of a seed unit, the reaction of corn plants to change in the background of mineral nutrition and density of plants were determined.

The article presents the results of the study on the determination of the effect of irrigation, doses of mineral fertilizers and plant density on the photosynthetic parameters of grain corn. It was determined that the maximum development of the leaf area was reached in the period of flowering on all the studied variants. The highest level of photosynthetic activity of plants and the yield of corn grain was fixed at the biologically optimal regime of irrigation, 
application of mineral fertilizers in the dose $\mathrm{N}_{120} \mathrm{P}_{90}$ and the density of plants 80 thousand/ha. The study determined that the yield of corn seeds on the plots of hybridization reached the maximum level of $9.1 \mathrm{t} / \mathrm{ha}$ in the variant with the biologically optimal regime of irrigation $(70-80-70 \%$ FC in the soil layer $0-50 \mathrm{~cm}$ ) at the recommended dose of fertilizers $\mathrm{N}_{120} \mathrm{P}_{90}$ and plant density 80 thousand pcs/ha.

\section{REFERENCES}

1. Лавриненко Ю.О., Вожегова Р.А., Коковіхін С.В. та ін. Кукурудза на зрошуваних землях півдня України: монографія. Херсон: Айлант, 2011. 468 c.

2. Нікішенко В.Л., Писаренко В.А. та ін. Методичні вказівки 3 планування та управління еколого-безпечними, водозберігаючими й економічно обгрунтованими режимами зрошення сільськогосподарських культур. Херсон: Олді-плюс, 2010. 152 с.

3. Вожегова Р.А., Лавриненко Ю.О., Малярчук М.П., Власенко О.О. та ін. Наукові підходи до формування технології вирощування зернових та технічних культур в умовах 2011 року: науково-методичні рекомендації. Херсон: Айлант, 2011. 36 с.

4. Алиев Д.А. Фотосинтетическая деятельность растений в посевах, минеральное питание и продуктивность растений. Баку: ЭЛМ, 1974. $335 \mathrm{c}$.

5. Косарський В.Ю., Грицун О.Л., Патюшенко С.О. Вплив густоти рослин на врожайність зерна кукурудзи. Агроном. 2010. № 3. C. $70-72$.

6. Вожегова Р.А., Лавриненко Ю.О., Коковіхін С.В., Грабовський П.В. та ін. Еколого-меліоративне та економічне обгрунтування ефективності систем управління продукційними i технологічними процесами основних культур на зрошуваних землях південного регіону. Херсон: ВЦ ІЗПР НААН України, 2010. 26 с.

7. Гуляев Б.И. Количественные основы взаимосвязи фотосинтеза, роста и продуктивности растений: автор. дис. работы доктора биол. наук, ИФР АН УССР / Б.И.Гуляев. К., 1983. 49 с.

8. Лавриненко Ю.О., Рубан В.Б., Михаленко І.В. Наукове обгрунтування технології вирощування кукурудзи при краплинному зрошенні: монографія. Херсон: Айлант, 2014. 194 с.

9. Системи землеробства на зрошуваних землях України / За наук. ред. Р.А. Вожегової. К.: Аграрн. наука, 2014. 360 с.

10. Андрієнко А.Л. Основні заходи сортової агротехніки гібридів кукурудзи різних груп стиглості в північному Степу України: автореф. дис. ... канд. с.-Г. наук: спец. 06.01 .09 «Рослинництво» / А.Л. Андрієнко. Дніпропетровськ, 2004. 19 с. 
11. Дзюбецький Б.В., Писаренко В.А., Лавриненко Ю.О., Коковіхін С.В. Морфо-фізіологічні показники продукційного процесу та врожай насіння материнської форми гібрида кукурудзи Борисфен 433 МВ в умовах зрошення. Бюл. Інституту зернового господарства УААН. 2000. № 14. С. $20-22$.

12. Лавриненко Ю.О., Коковіхін С.В., Писаренко П.В.Екологічна мінливість показників темпів розвитку рослин кукурудзи. Таврійський науковий вісник: зб. наук. пр. Херсон: Айлант, 2005. Вип. 40. С. 46-55.

13. Ничипорович А.А. Основы фотосинтетической продуктивности растений. Современные проблемы фотосинтеза. М.: МГУ, 1973. C. 5-28.

14. Надь Янош Кукурудза. Вінниця: ФОП Корзун Д.Ю., 2012. 580 с.

\section{Information about the author:} Piliarska O. O., Candidate of Agricultural Sciences (PhD in Agriculture), Senior Researcher Institute of Irrigated Agriculture of the National Academy of Agrarian Sciences of Ukraine Kherson, Naddnipryanske, 73483, Ukraine 